\title{
PENGARUH KECAKAPAN PROFESIONAL DAN PENGALAMAN KERJA TERHADAP KUALITAS HASIL PEMERIKSAAN PADA KANTOR INSPEKTORAT KABUPATEN KEPULAUAN TALAUD DENGAN KEPATUHAN PADA KODE ETIK SEBAGAI VARIABEL MODERATING
}

\author{
FERDY LAY ${ }^{1)}$, HERMAN KARAMOY ${ }^{2)}$, JENNY MORASA ${ }^{3)}$ \\ Program Studi Akuntansi Fakultas Ekonomi dan bisnis Universitas Sam Ratulangi \\ E-mail: ferdy lay@yahoo.com
}

\begin{abstract}
The quality of the results of inspection is a complex issue, because so many factors that can affect the quality of the audit which depends on the point of view of each personal. The purpose of this study is to determine the effect of professional skills and work experience to the quality of examination results with adherence to the code of ethics as a moderating variable in the Inspectorate Talaud Islands. The population of this research is all internal auditors in Inspectorate Talaud Islands. Total respondents are 34 internal auditors who have worked in the Inspectorate Talaud Islands. The data were analyzed by using multiple linear regression analysis. To examine the $f$ test moderation, moderated regression analysis (MRA) was employed. Result indicates that professional skill positively and significantly influences the quality of inspection result. On the other hand, work experience positively and insignificantly influences the quality of inspection result. It means that obeying the code ethics positively and significantly influences the quality of inspection result. Furthermore, professional skill that moderated on obeying code ethics does not influence the quality of inspection result; and work experience that moderated on obeying to code ethics does not influence the quality of inspection result.
\end{abstract}

Keywords: professional skills, experience, adherence to a code of ethics, quality examination results.

\begin{abstract}
Abstrak. Kualitas hasil pemeriksaan merupakan suatu issue yang kompleks, karena begitu banyak faktor yang dapat mempengaruhi kualitas audit, yang tergantung dari sudut pandang masing-masing pihak. Tujuan dari penelitian ini adalah untuk mengetahui pengaruh kecakapan profesional dan pengalaman kerja terhadap kualitas hasil pemeriksaan dengan kepatuhan pada kode etik sebagai variabel moderating, pada Inspektorat Kabupaten Kepulauan Talaud. Populasi dari penelitian ini adalah seluruh auditor internal pada Inspektorat Kabupaten Kepulauan Talaud dengan responden sebanyak 34 orang auditor internal yang bekerja di Inspektorat Kabupaten Kepulauan Talaud. Pengujian hipotesis penelitian menggunakan analisis regresi linier berganda dan untuk uji moderasi menggunakan Moderated Regression Analyisis (MRA). Hasil penelitian menunjukan bahwa kecakapan profesional berpengaruh positif dan signifikan terhadap kualitas hasil pemeriksaan, pengalaman kerja berpengaruh positif tapi tidak signifikan terhadap kualitas hasil pemeriksaan, kepatuhan pada kode etik berpengaruh positif dan signifikan terhadap kualitas hasil pemeriksaan, kecakapan profesional yang dimoderasi kepatuhan pada kode etik tidak berpengaruh terhadap kualitas hasil pemeriksaan dan pengalaman kerja yang dimoderasi kepatuhan pada kode etik tidak berpengaruh terhadap kualitas hasil pemeriksaan.
\end{abstract}

Kata kunci : kecakapan profesional, pengalaman, kepatuhan pada kode etik, kualitas hasil pemeriksaan. 


\section{Pendahuluan}

Dalam era otonomi sekarang ini pemerintah dituntut dalam penyelenggaraan pemerintahan untuk dapat mewujudkan good governance dengan melakukan perubahan yang mendasar dan juga mengoptimalkan sumber daya yang ada. Dengan diterbitkannnya Undang - Undang Nomor 9 Tahun 2015 tentang perubahan kedua atas undang-undang nomor 23 tahun 2014 tentang pemerintahan daerah. Maka arah pelaksanaan desentralisasi atau otonomi daerah yang luas, bertanggungjawab dan nyata.

Untuk mewujudkan pemerintahan yang baik diperlukan komitmen dari semua pihak (pemerintah dan masyarakat). Wujud pemerintahan yang baik (good governance) adalah penyelenggaraan negara yang solid, bertanggungjawab, efektif dan efisien dengan mensinergikan interaksi antar lembaga-lembaga negara. Memang sangat wajar jika tuntutan penyelenggaraan pemerintahan dalam terwujudnya good governance meningkat.

Terdapat tiga aspek utama yang menurut Mardiasmo dapat mendukung terciptannya good governance, yaitu pengawasan, pengendalian, dan pemeriksaan. Pengawasan internal pemerintah merupakan fungsi manajemen yang penting dalam penyelenggaraan pemerintahan. Melalui pengawasan internal dapat diketahui apakah suatu instansi telah melaksanakan sesuai tugas dan fungsinya secara efektif dan efisien, serta sesuai dengan rencana, kebijakan yang telah ditetapkan dan ditentukan, pengawasan internal atas pemerintahan juga diperlukan untuk mendorong terwujudnya good governance dan clean governance serta mendukung pemerintahan yang efektif, efisien, transparan, akuntanbel serta bersih dan bebas dari praktik korupsi, kolusi dan nepotisme.

Untuk melaksanakan tugas pengawasan internal pemerintah Kabupaten Kepulauan Talaud, maka dibentuklah Inspektorat dengan Peraturan Daerah Kabupaten Kepulauan Talaud Nomor 31 Tahun 2008 badan pengawas daerah Kabupaten Kepulauan Talaud berubah menjadi Inspektorat Kabupaten Kepulauan Talaud. Inspektorat mempunyai tugas pokok melakukan kewenangan Bupati di bidang pengawasan fungsional penyelenggaraan pemerintahan daerah, pengawasan penyelenggaraan pemerintahan daerah Kabupaten Kepulauan Talaud.

Pemeriksaan/audit yang dilaksanakan oleh Inspektorat Kabupaten Kepulauan Talaud yaitu audit operasional, audit dengan tujuan tertentu (pemeriksaan khusus) dan reviu laporan keuangan daerah. Audit kinerja atau audit operasional adalah pemeriksaan atas pengelolaan keuangan daerah pada SKPD yang meliputi aspek ekonomis, efisien dan efektivitas. Audit operasional ini dilaksanakan secara berkala, 4 kali dalam setahun pada seluruh entitas dilingkungan pemerintah Kabupaten Kepulauan Talaud sehingga disebut pemeriksaan reguler. Pada pemeriksaan ini auditor ditutut untuk dapat mendeteksi kegiatan yang dilaksanakan oleh entitas telah sesuai dengan tugas pokok dan fungsi serta ekonomis, efisien dan efektif.

Aparat pengawas internal pemerintah juga melakukan reviu atas laporan keuangan pemerintah daerah ini sesuai dengan amanat peraturan pemerintah nomor 4 tahun 2008 tentang pedoman pelaksanaan reviu atas laporan keuangan pemerintah daerah. Inspektorat Kabupaten Kepulauan Talaud juga melaksanakan reviu atas laporan keuangan pemerintah Kabupaten Kepulauan Talaud sebelum laporan tersebut diserahkan ke BPK RI untuk dilakukan pemeriksaan atas laporan keuangan tersebut. Salah satu tujuan dilakukannya reviu tersebut yaitu untuk memberikan opini terbatas atas laporan keuangan tersebut untuk meyakinkan bahwa penyusunan laporan keuangan tersebut telah sesuai dengan standar akuntansi pemerintah (SAP) sehingga pada saat diaudit oleh BPK tidak terdapat lagi permasalahan yang material.

Namun pada kenyataannya hasil pemeriksaan yang dilaksanakan oleh aparat Inspektorat Kabupaten Kepulauan Talaud saat ini masih menjadi sorotan, dan memunculkan banyak pertanyaaan. Hal ini disebabkan masih banyak temuan yang tidak dapat dideteksi oleh aparat Inspektorat sebagai auditor internal, akan tetapi ditemukan oleh auditor external yaitu badan pemeriksa keuangan (BPK). Temuan-temuan tersebut berupa ketidakpatuhan terhadap peraturan perudang-undangan, 
kecurangan, dan ketidakpatuhan dalam pelaporan keuangan serta sistem pengendalian yang tidak memadai yang sebagian berujung pada kerugian daerah.

Berdasarkan ikhtisar hasil pemeriksaan semester 1 Tahun 2014 terdapat 28 kasus temuan yang merugikan negara sebesar Rp. 754.435.000,- juga dalam pemberian opini terhadap LKPD Kabupaten Kepulauan Talaud pada tahun 2014 dan tahun 2015 baru mendapatkan opini WDP sejak tahun 2003 awal pemeriksaan oleh BPK. Fenomena yang ada menimbulkan dugaan akan adanya permasalahan mengenai latar pendidikan, kecakapan professional, pendidikan berkelanjutan dan pengalaman yang renda membuat auditor tidak mampu mendeteksi, menemukan dan mengungkap penyimpanganpenyimpangan yang terjadi dan berujung pada kerugian daerah. Pemahaman akan pentingnya audit yang berkualitas bagi terwujudnya pemerintahan yang akuntanbel akan mampu memotivasi aparat Inspektorat untuk meningkatkan pendidikan, kecakapan professional, pendidikan berkelanjutan dan pengalaman yang dimilikinya agar dapat menunjang kualitas hasil pemeriksaan yang dilakukan oleh Inspektorat itu sendiri.

Berdasarkan pemikiran tersebut, beberapa hal yang menjadi fokus dalam tulisan ini adalah mencakup pengaruh kecakapan professional dan pengalaman kerja pada inspektorat kabupaten kepulauan talaud yang dimoderasi dengan kepatuhan pada kode etik, yang divisualisasikan dalam kerangka berpikir sebagaimana pada gambar 1 .

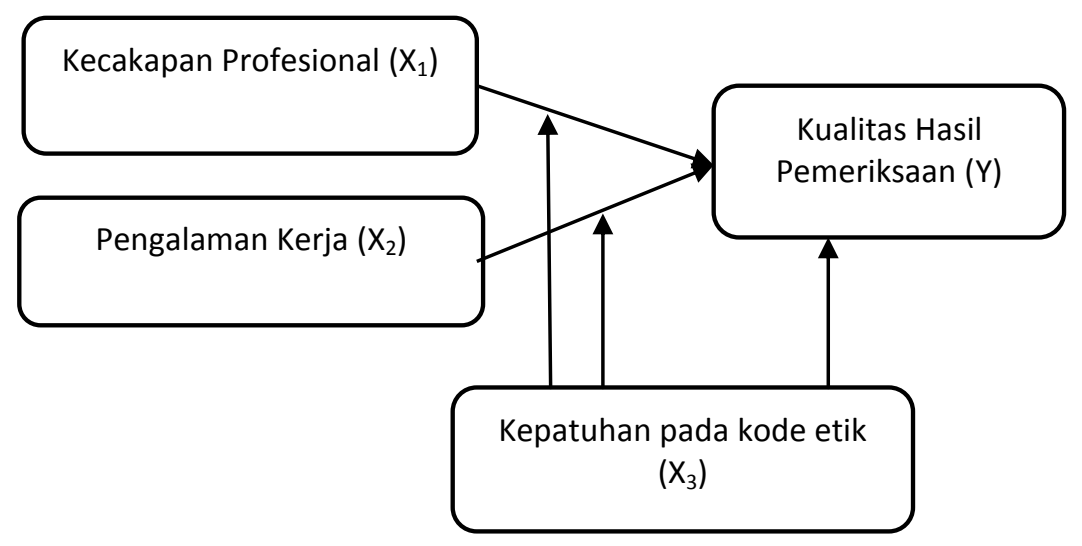

Gambar 1. Kerangka Pemikiran

Pemeriksaan adalah merupakan teknik pengawasan yaitu kegiatan untuk menilai apakah hasil pelaksanaan yang sebenarnya telah sesuai dengan yang seharusnya dan untuk mengidentifikasi penyimpangan atau hambatan yang ditemukan. Auditor mempunyai kewajiban untuk melaksanakan jasa profesional dengan sebaik-baiknya sesuai dengan kemampuannya, demi kepentingan pengguna jasa dan konsisten dengan tanggung jawab profesi publik (Mulyadi, (2002). Kehati-hatian profesional adalah auditor diharuskan untuk merencanakan dan mengawasi secara seksama.

Dalam rangka pelaksanaan pengawasan dan pemeriksaan yang baik di lingkungan pemerintah daerah, Aparat pengawasan intern pemerintah (APIP) harus memiliki kualitas sumber daya manusia yang didukung pengalaman dan pengetahuan yang memadai dalam praktik pemeriksaan serta pelatihan teknis yang cukup tentang tehnik dan etika sebagai aparat pengawas internal pemerintah. Keahlian aparat pengawas terbentuk karena pengalaman kerja dan pengetahuan aparat pengawas. Disamping itu pengalaman kerja juga akan mempengaruhi tingkat pengetahuan aparat pengawasan intern pemerintah (APIP).

Semakin banyak pengalaman yang aparat pengawas dapati maka akan semakin tinggi pengetahuan mereka tentang bidang tersebut. Pengaruh pengalaman terhadap pengetahuan sangatlah penting diperlukan dalam rangka kewajiban aparat pengawas terhadap tugasnya untuk memenuhi standar umum audit (Batubara, 2009). Effendi (2011) mendefinisikan pengalaman kerja 
adalah tingkat penguasaan pengetahuan serta keterampilan seseorang dalam pekerjaannya yang dapat diukur dari masa kerja, dari tingkat pengetahuan serta keterampilan yang dimilikinya.

\section{Metode Penelitian}

Penelitian ini merupakan jenis penelitian kuantitatif yang bertujuan memberikan bukti empiris pengaruh kecakapan profesional (X1), pengalaman kerja (X2), kepatuhan pada kode etik (X3), sebagai variabel independen terhadap kualitas hasil pemeriksaan variabel dependen. Teknik analisis yang digunakan adalah analisis regresi berganda dengan Uji Moderated Regression Analyisis (MRA).

Penelitianini dilakukan pada Pemerintah Kabupaten Kepulauan Talaud Provinsi Sulawesi Utara. Populasi yang digunakan adalah Aparat Pengawas Internal Pemerintah sejumlah 34 orang pada kantor Inspektorat di Pemerintah Kabupaten Kepulauan Talaud.

Teknik pengambilan sampel dalam penelitian ini dilakukan secara kausal. Kecakapan Profesional diukur dengan training, rekomendasi, ketrampilan dengan menggunakan 7 (tujuh) pernyataan. Pengalaman kerja diukur dengan suatu aktivitas nyata dengan baik dan professional dengan menggunakan 6 (enam) pernyataan. Kepatuhan pada kode etik diukur dengan integritas, obyektifitas, kerahasiaan, dan kompetensi dengan menggunakan 14 (empat belas) pernyataan. Kualitas kualitas hasil pemeriksaan diukur dengan akurat temuan, rekomendasi, laporan audit dan tindak lanjut. dengan menggunakan 7 (tujuh) pernyataan. Masing-masing item pernyataan tersebut kemudian diukur dengan menggunakan Skala Likert 5 point.

\section{Hasil dan Pembahasan}

Data dalam penelitian ini yaitu data primer yang dikumpulkan dengan cara menyebarkan kuesioner langsung kepada 35 responden di kantor inspektorat Kabupaten Kepulauan Talaud. Sebanyak 35 kuesioner yang disebarkan, terkumpul sebanyak 34 kuesioner, hal ini disebabkan karena pada saat dikumpul, beberapa kuesioner tidak dikembalikan oleh responden. Dari 34 kuesioner yang dikembalikan, terdapat 1 kuesioner yang tidak dapat digunakan karena yang bersangkutan tidak berada ditempat sampai selesai pengumpulan kuesioner, sehingga kuesioner yang dapat diolah sebanyak 34 kuesioner.

Untuk mendapatkan kualitas data dari suatu instrumen telah dilakukan uji validitas dan reliabilitas. Pengujian validitas dalam penelitian ini menggunakan Pearson Correlation yaitu dengan cara menghitung korelasi antara skor masing-masing butir pernyataan dengan skor total. Jika korelasi antara skor masing-masing butir pernyataan dengan skor total mempunyai tingkat signifikansi $<0,05$, maka butir pernyataan tersebut dinyatakan valid dan sebaliknya. Hasil uji coba menunjukkan bahwa semua item pernyataan untuk variabel kecakapan profesional, pengalaman kerja dan kepatuhan pada kode etik kriteria valid dengan nilai signifikansi $<0,05$. Hal ini berarti semua item pernyataan yang digunakan dalam penelitian ini mampu mengungkapkan semua variabel yang diukur pada kuesioner tersebut.

Pengujian reliabilitas dilakukan menggunakan teknik Cronbach Alpha. Suatu instrumen dapat dikatakan reliabel bila memiliki koefisien keandalan atau Cronbach Alpha $\geq 0,60$. Berdasarkan uji reliabilitas menunjukkan nilai Cronbach's Alpha untuk variabel kecakapan professional sebesar 0,737; pengalaman kerja sebesar 0,759; kepatuhan pada kode etik sebesar 0,760; dan. Dengan demikian dapat disimpulkan bahwa pernyataan dalam kuesioner ini reliable karena memiliki nilai Cronbach's Alpha $>0,60$. Hal ini menunjukkan bahwa apabila pernyataan diajukan kembali akan diperoleh jawaban yang relatif sama dengan jawaban sebelumnya.

Uji normalitas dilakukan untuk mengetahui data berdistribusi normal. Uji normalitas dalam penelitian ini dengan menggunakan grafik P-Plot SPSS dan uji normalitas Kolmogorov-Smirnov. Melalui grafik P-Plot dapat dinilai dari titik-titik penyebaran disekitar garis diagonal apakah searah dan mengikuti garis diagonal, sedangkan pada uji normalitas Kolmogorov-Smirnov akan dilihat nilai 
signifikansinya apabila lebih dari 0,05 maka data tersebut berdistribusi normal. Berdasarkan uji normalitas dengan grafik P-Plot SPSS, didapatkan bahwa titik data menyebar di sekitar garis diagonal dan penyebaran titik-titik data searah mengikuti garis diagonal. Berdasarkan uji normalitas Kolmogorov-Smirnov dilihat bahwa nilai asymp.sig (2-tailed) atau signifikansi sebesar 0,528 lebih besar dari 0.05 sehingga dapat disimpulkan bahwa data yang diuji berdistribusi normal. Dengan demikian model regresi telah memenuhi asumsi normalitas.

Pengujian multikolinieritas dilakukan untuk melihat apakah pada model regresi ditemukan adanya korelasi antara variabel independen. Cara mendeteksinya adalah dengan melihat nilai tolerancedan nilai Variance Inflation Factor (VIF). Jika nilai VIF < 10 dan tolerance $>0,1$ maka variabel independen terbebas dari persoalan multikolinieritas. Hasil uji SPSS menunjukkan bahwa semua nilai tolerance $>0,1$ dan nilai VIF $<10$. Hasil uji SPSS menunjukkan bahwa semua nilai tolerance $>0,1$ dan nilai VIF $<10$. Hal ini menunjukkan bahwa semua variabel independen terbebas dari multikolinieritas.

Uji heterokedastisitas dilakukan untuk mengetahui apakah dalam sebuah model regresi terjadi ketidaksamaan varians dari residual suatu pengamatan ke pengamatan lain. Ada tidaknya heteroskedastisitas dapat ditentukan dengan melihat grafik plot antara nilai prediksi variabel terikat dengan residual. Jika grafik plot menunjukkan suatu pola titik yang bergelombang atau melebar kemudian menyempit, maka dapat disimpulkan bahwa telah terjadi heteroskedastisitas. Namun jika tidak ada pola yang jelas, yaitu serat titik-titik menyebar di atas dan di bawah angka 0 pada sumbu $Y$, maka tidak terjadi heteroskedastisitas. Hasil uji menunjukkan bahwa pada scatterplot, titik-titik yang ada tidak membentuk sebuah pola namun menyebar, sehingga dapat disimpulkan bahwa dalam penelitian tidak terjadi heterokedastisitas.

Hasil pengujian asumsi klasik menunjukkan bahwa model regresi yang dipakai telah memenuhi asumsi klasik sehingga dapat dilanjutkan dengan analisis regresi berganda dan Moderated Regression Anlyisis(MRA). Model regresi berganda dalam penelitian ini adalah untuk menguji pengaruh kecakapan profesional $\left(X_{1}\right)$, pengalaman kerja $\left(X_{2}\right)$, kepatuhan pada kode etik $\left(X_{3}\right)$ dan kualitas hasil pemeriksaan $\left(\mathrm{X}_{4}\right)$, terhadap kualitas laporan keuangan pemerintah daerah $(\mathrm{Y})$. Hasil analisis regresi linear berganda-Moderated Regression Anlyisis(MRA) pada tabel 1 berikut.

\begin{tabular}{|c|c|c|c|c|c|}
\hline \multicolumn{6}{|c|}{ Coefficients $^{\mathrm{a}}$} \\
\hline \multirow[t]{2}{*}{ Model } & \multicolumn{2}{|c|}{$\begin{array}{l}\text { Unstandardized } \\
\text { Coefficients }\end{array}$} & \multirow{2}{*}{$\begin{array}{c}\text { Standardized } \\
\text { Coefficients }\end{array}$} & \multirow[t]{2}{*}{$t$} & \multirow[t]{2}{*}{ Sig. } \\
\hline & $B$ & Std. Error & & & \\
\hline (Constant) & -15.039 & 5.393 & & -2.788 & .009 \\
\hline X1 & .400 & .145 & .281 & 2.751 & .010 \\
\hline${ }^{1} \times 2$ & .244 & .186 & .132 & 1.313 & 199 \\
\hline$x 3$ & .451 & .082 & .622 & 5.525 & .000 \\
\hline (Constant) & 117.414 & 112.398 & & -1.045 & .305 \\
\hline $\mathrm{X} 1$ & .658 & 2.648 & .461 & .248 & .806 \\
\hline $2 \times 2$ & 3.467 & 3.549 & 1.881 & .977 & .337 \\
\hline X3 & 2.175 & 1.893 & 2.995 & 1.149 & .260 \\
\hline X1.X3 & -.005 & .044 & -.331 & -.102 & .919 \\
\hline$\times 2 . X 3$ & -.054 & .059 & -3.398 & -.911 & .370 \\
\hline
\end{tabular}

a. Dependent Variable: $Y$

Pengujian hipotesis dengan uji $\mathrm{F}$ (Fisher Test) Model 1 (satu) nilai Fhitung sebesar 33.058 dengan signifikan 0,000. Karena signifikansi jauh lebih kecil dari nilai signifikan 0.05 , maka model regresi ini dapat digunakan untuk memprediksi kualitas hasil pemeriksaan. Jika nilai $F_{\text {tabel }}$ dibandingkan dengan 
$F_{\text {hitung }}$ maka dapat diketahui bahwa nilai $F_{\text {hitung }}$ (33.058) lebih besar dari nilai $F_{\text {tabel }}(2,54)$. Hal ini dapat diinterpretasikan bahwa variable kecakapan profesional (X1), pengalaman kerja (X2), kepatuhan pada Kode Etik (X3) secara bersama - sama mempengaruhi variabel kualitas hasil pemeriksaan.

Model 2 (dua) nilai $F_{\text {hitung }}$ sebesar 19,364 dengan signifikan 0,000. Karena signifikansi jauh lebih kecil dari nilai signifikan 0.05 , maka model regresi ini dapat digunakan untuk memprediksi kualitas hasil pemeriksaan. Jika nilai $F_{\text {tabel }}$ dibandingkan dengan $F_{\text {hitung }}$ maka dapat diketahui bahwa nilai Fhitung (19.364) lebih besar dari nilai $F_{\text {tabel }}(2,54)$. Hal ini dapat diinterpretasikan bahwa variable kecakapan profesional (X1), pengalaman kerja (X2), kepatuhan pada kode etik (X3) secara bersama sama mempengaruhi varaiabel kualitas hasil pemeriksaan.

Pengujian hipotesis dengan uji t (uji Parsial) Dari Model 1 (satu), variable pengalaman kerja (X2) memiliki nilai signifikan 0,199, variabel tersebut menunjukan bahwa $t_{\text {hitung }}$ lebih besar dari $t_{\text {tabel }}$ $(1.313>2,045)$ jadi ini menunjukan bahwa pengalaman kerja berpengaruh positif tapi tidak signifikan terhadap kualitas hasil pemeriksaan. Namun kecakapan profesional (X1) sig. 0,229 kurang dari nilai signifikansi 0,05 dengan $t_{\text {hitung }}$ lebih besar dari $t_{\text {tabel }}(2.752>2.045)$ dan kepatuhan pada kode etik (X3) sig. 0,0000 dengan nilai signifikannya kurang dari nilai signifikansi 0,05 dengan $t_{\text {hitung }}$ lebih besar dari $t_{\text {tabel }}(5,525>2.045)$ masing-masing variabel hal ini menunjukan tidapk ada pengaruh terhadap kualitas hasil pemeriksaan

Untuk model 2 (dua) menunjukan bahwa interaksi variabel kecakapan profesional nilai signifikan 0.919, interaksi variable pengalaman Kerja dengan kepatuhan pada kode etik nilai signifikan 0.370, interaksi kecakapan professional dengan dengan kepatuhan pada kode etik nilai signifikan 0.102 dengan $t_{\text {hitung }}$ lebih kecil dari $t_{\text {tabel. }}$. Hal ini membuktikan bahwa interaksi kedua variable independen dengan kepatuhan pada kode mempunyai tidak ada pengaruh terhadap kualitas hasil pemeriksaan karena ke kedua bukan variabel moderat.

Uji koefisien determinasi dalam regresi linear berganda, untuk regresi dengan lebih dari dua variabel bebas digunakan adjusted $R^{2}$ sebagai koefisien determinasi. Berdasarkan hasil uji, Dari model 1 (satu) besarnya adjusted $R^{2}$ adalah 0.762 . Nilai ini dapat menjelaskan bahwa $76.2 \%$ variasi kualitas hasil pemeriksaan dapat dijelaskan oleh variasi dari variable kecakapan profesional (X1), pengalaman kerja (X2), kepatuhan pada Kode Etik (X3) dan sisanya 23,8\% dipengaruhi oleh variable yang tidak teramati diluar model.

Untuk model 2 (dua) besarnya adjusted $R 2$ adalah 0.770 . Nilai ini dapat menjelaskan bahwa 77.0 $\%$ variasi kualitas hasil pemeriksaan dapat dijelaskan oleh interaksi dari kecakapan Profesional dengan kepatuhan pada kode etik (X1.X3), pengalaman kerja dengan kepatuhan pada kode etik (X2.X3), sisanya adalah $23 \%$ dipengaruhi oleh variable yang tidak teramati diluar model.

\section{Pengaruh kecakapan professional terhadap kualitas hasil pemeriksaan}

Hasil pengujian hipotesis pertama menyatakan bahwa Kecakapan Profesional berpengaruh positif dan signifikan pada kualitas hasil pemeriksaan. Hasil analisis menunjukkan bahwa kecakapan professional tidak berpengaruh pada kualitas hasil pemeriksaan. Hasil ini menunjukkan Hipotesis 1 (Ha1) ditolak. Hal tersebut dapat terlihat dari koefisien regresi kecakapan profesional sebesar 0,400 diatas nilai kepercayaan 0,05 dan signifikan karena nilai $t_{\text {hitung }}>t_{\text {tabel }}(2.751<2.045)$. Hal ini menunjukan bahwa kecakapan profesional berpengaruh positif dan signifikan terhadap kualitas hasil pemeriksaan.

Hasil penelitian ini sesuai dengan penelitian yang dilakukan oleh Rizal Iskandar Batubara (2008), tentang analisis pengaruh latar belakang pendidikan, kecakapan professional, pendidikan berkelanjutan dan independensi terhadap kualitas hasil pemeriksaan Inspektorat Provinsi medan, dimana kecakapan professional berpengaruh terhadap kualitas hasil pemeriksaan. 
Simpulan dari penelitian ini bahwa kecakapan professional berpengaruh positif dan signifikan terhadap kualitas hasil pemeriksaan Inspektorat Kabupaten Kepulauan Talaud. Artinya kecakapan profesional yang rendah akan berdampak pada rendahnya kualitas hasil pemeriksaan

\section{Pengaruh pengalaman kerja terhadap kualitas hasiln pemeriksaan}

Hasil pengujian hipotesis kedua menyatakan bahwa pengalaman kerja berpengaruh positif namun signifikan pada kualitas hasil pemeriksaan. Hasil analisis menunjukkan bahwa pengalaman kerja berpengaruh positif namun signifikan pada kualitas hasil pemeriksaan. Hasil ini menunjukkan Hipotesis 2 ( $\mathrm{Ha} 2$ ) ditolak. Hal tersebut dapat terlihat dari koefisien regresi pengalaman kerja sebesar 0,244 diatas nilai kepercayaan 0,05 dan signifikan karena nilai $t_{\text {hitung }}>t_{\text {tabel }}$ (1.313. $>2.045$ ). Hal ini menunjukan bahwa pengalaman kerja hanya menunjukan Pengaruh positif namun signifikan terhadap kualitas hasil pemeriksaan.

Hasil penelitian hipotesis ini sejalan dengan Syamsidah (2016) Pengalaman berpengaruh positif terhadap kualitas audit, artinya dengan semakin seringnya auditor melaksanakan tugas audit, maka pengalaman dan pengetahuan akan semakin bertambah, sehingga kepercayaan auditor semakin bertambah besar dan kualitas audit yang dihasilkan semakin baik.

Hasil penelitian ini sesuai Peraturan Menteri Pemberdayaan Aparatur Negara No. Per/05/M.Pan/03/2008 tangal 31 Maret 2008 tentang standar audit bagi aparat pengawas intern pemerintah (APIP) bahwa pimpinan APIP bertanggung jawab kepada pimpinan tertinggi organisasi agar tanggung jawab pelaksanaan audit dapat terpenuhi. Posisi APIP ditempatkan secara tepat sehingga bebas dari intervensi, dan memperoleh dukungan yang memadai dari pimpinan tertinggi organisasi sehingga dapat bekerjasama dengan auditi dan melaksanakan pekerjaan dengan leluasa. Kesimpulan dari penelitian ini bahwa semakin tinggi pengalaman kerja maka akan semakin baik kualitas hasil pemeriksaan

\section{Pengaruh kepatuhan pada kode etik terhadap Kualitas hasil pemeriksaan.}

Hasil pengujian hipotesis ketiga menyatakan bahwa kepatuhan pada kode etik berpengaruh positif dan signifikan pada kualitas hasil pemeriksaan. Hasil analisis menunjukkan bahwa kepatuhan pada kode etik berpengaruh positif dan signifikan terhadap kualitas hasil pemeriksaan. Hasil ini menunjukkan Hipotesis 3 ( $\mathrm{Ha} 3$ ) diterima. Posisi ini terlihat dari koefisien regresi kepatuhan pada kode etik sebesar 0,451 diatas nilai kepercayaan 0,05 dan signifikan karena nilai $t_{\text {hitung }}>t_{\text {tabel }}(5,525>$ 2.045). Hal ini menunjukan bahwa kepatuhan pada kode etik menunjukan pengaruh positif dan signifikan terhadap kualitas hasil pemeriksaan.

Penelitian ini sejalan dengan penelitian yang dilakukan oleh Ananda, (2014) yang menemukan data empiris bahwa kepatuhan pada kode etik berpengaruh signifikan positif terhadap kualitas audit. Artinya, semakin tinggi kepatuhan pada kode etik maka akan semakin baik pula kualitas audit pemerintahan. Demikian pula dengan penelitian Lubis (2009) yang membuktikan pengaruh kepatuhan pada kode etik terhadap kualitas auditor adalah positif dan signifikan. Hal ini menunjukan bahwa kepatuhan pada kode etik mempunyai peranan yang penting dalam meningkatkan kualitas auditor.

\section{Pengaruh Kecakapan Profesional yang dimoderasi Kepatuhan Pada Kode Etik Terhadap Kualitas Hasil Pemeriksaan}

Hasil pengujian hipotesis keempat menyatakan bahwa kecakapan professional yang dimoderasi dengan kepatuhan pada kode etik tidak berpengaruh terhadap kualitas hasil pemeriksaan. Hasil analisis menunjukkan bahwa kecakapan profesional yang dimoderasi dengan kepatuhan pada kode etik tidak berpengaruh pada kualitas hasil pemeriksaan. Hasil ini menunjukkan Hipotesis 4 ( $\mathrm{Ha} 4)$ ditolak. Posisi ini terlihat dari koefisien regresi kecakapan professional yang dimoderasi dengan kepatuhan pada kode etik sebesar -0,005 diatas bawah kepercayaan 0,05 dan 
tidak signifikan karena nilai $t_{\text {hitung }}<t_{\text {tabel }}(-0.102<2.045)$. Hal ini menunjukan bahwa kecakapan profesional yang dimoderasi dengan kepatuhan pada kode etik menunjukan bahwa tidak ada pengaruh terhadap kualitas hasil pemeriksaan.

Berdasarkan teori disonansi kognitif, auditor dengan kepatuhan kode etik tinggi akan mengurangi disonansi dengan mengambil keputusan audit yang paling tepat untuk mendapatkan hasil audit yang berkualitas. Auditor tersebut akan berhati-hati dalam memutuskan karena tidak ingin melanggar kode etik. Kehati-hatian ini mendorong auditor untuk memiliki sifat skeptis yang lebih tinggi, yaitu dengan menunda penilaian sebelum cukup yakin dengan bukti audit yang ada. Sebaliknya, auditor dengan kepatuhan kode etik rendah mengurangi disonansi dengan mengabaikan isu audit yang ada. Auditor ini tidak mengevaluasi lebih dalam kecukupan bukti audit. Semakin tinggi kepatuhan dan kesadaran auditor terhadap kode etik profesinya, maka auditor akan cenderung lebih berhati-hati ketika melaksanakan audit serta tidak dengan mudah percaya terhadap pernyataan klien dengan melaksanakan lebih banyak pemeriksaan ulang, yang pada akhirnya akan meningkatkan keakuratan hasil auditnya (Oktarini \& Ramantha, 2016).

Hasil penelitian ini tidak dapat menjawab teori disonansi kognitif karena kepatuhan pada kode etik yang diharapkan dapat mengurangi disonansi ternyata tidak mampu memberikan pengaruh signifikan pada kecakapan profesional terhadap kualitas audit. Sekalipun auditor patuh pada kode etik, dia tidak mampu menguatkan ataupun memperlemah sikap auditor untuk meningkatkan atau menurunkan kualitas pemeriksaan.

Dengan ini interaksi kecakapan professional dan kepatuhan pada kode etik bukan merupakan variabel moderat, sehingga dapat disimpulkan penelitian ini secara parsial kecakapan professional tidak mempunyai pengaruh terhadap kualitas hasil pemeriksaan yang dimoderasi dengan kepatuhan pada kode etik.

\section{Pengaruh Pengalaman Kerja yang dimoderasi Kepatuhan Pada Kode Etik Terhadap Kualitas Hasil Pemeriksaan.}

Hasil pengujian hipotesis kelima menyatakan bahwa pengalaman kerja yang dimoderasi dengan kepatuhan pada kode etik berpengaruh positif dan signifikan pada kualitas hasil pemeriksaan. Hasil analisis menunjukkan bahwa pengalaman kerja yang dimoderasi dengan kepatuhan pada kode etik tidak berpengaruh pada kualitas hasil pemeriksaan. Hasil ini menunjukkan Hipotesis 5 (Ha5) ditolak. Posisi ini terlihat dari koefisien regresi pengalaman kerja yang dimoderasi dengan kepatuhan pada kode etik sebesar -0,054 dibawah nilai kepercayaan 0,05 dan tidak signifikan karena nilai $t_{\text {hitung }}>t_{\text {tabel }}(-0,911>2.045)$. Hal ini menunjukan bahwa pengalaman kerja yang dimoderasi dengan kepatuhan pada kode etik menunjukan bahwa tdak terdapat pengaruh terhadap kualitas hasil pemeriksaan.

Dari hasil penelitian ini sejalan oleh Samsi (2013) Auditor yang mempunyai pengalaman kerja lebih lama mempunyai perilaku lebih etis dibanding auditor yang mempunyai pengalaman kerja yang singkat. Dalam menghasilkan laporan yang memiliki kualitas audit yang tinggi seorang auditor harus mentaati etika auditor yang telah ditetapkan. Semakin tinggi auditor mentaati etika auditor maka kualitas audit yang dihasilkan akan semakin tinggi. Namun semakin rendah auditor mentaati etika auditor maka kualitas yang dihasilkan semakin rendah. Sehingga auditor yang mempunyai pengalaman kerja lebih lama mempunyai perilaku lebih etis dibanding auditor yang mempunyai pengalaman kerja yang singkat.

Dengan ini interaksi pengalaman kerja dan kepatuhan pada kode etik bukan merupakan variabel moderat, sehingga dapat disimpulkan penelitian ini secara parsial pengalaman kerja tidak mempunyai pengaruh terhadap kualitas hasil pemeriksaan yang dimoderasi dengan kepatuhan pada kode etik.

Berdasarkan hasil pengujian statistikseperti yang telah dijelaskan sebelumnya terbukti interaksi kecakapan profesional dan pengalaman kerja bukan merupakan variabel moderat, sehingga 
penelitian ini menyimpulkan bahwa secara parsial kecakapan professional dan pengalaman kerja tidak berpengaruh terhadap kualitas hasil audit yang dimoderasi oleh kepatuhan pada kode etik.

\section{Kesimpulan dan Saran}

Hasil penelitian menunjukkan bahwa Secara simultan kecakapan professional, pengalaman berpengaruh positif dan signifikan terhadap kualitas hasil pemeriksaan. Secara parsial pengalaman berpengaruh positif namun tidak signifikan terhadap kualitas hasil pemeriksaan. Secara parsial kecakapan professional dan kepatuhan pada kode etik berpengaruh positif dan signifikan terhadap kualitas hasil pemeriksaan. Secara simultan kecakapan professional, pengalaman berpengaruh positif dan signifikan terhadap kualitas hasil pemeriksaan yang dimoderasi dengan kepatuhan pada kode etik.

Secara parsial kecakapan professional dan pengalaman kerja yang dimoderasi oleh kepatuhan pada kode etik tidak berpengaruh posistif dan signifikan terhadap kualitas hasil pemeriksaan. Saran yang dapat diberikan dalam penelitian ini agar Inspektorat Kabupaten Kepulauan Talaud, 1) Disarankan bagi pengawas internal meningkatkan kecakapan profesional yang tinggi dalam melaksanakan audit sehingga dapat menghasilkan pemeriksaan yang berkualitas, 2) Pengalaman kerja yang tinggi haruslah dipertahankan oleh seorang auditor internal, untuk menghasilkan audit yang berkualitas. 3) Auditor harus meyakini bahwa prinsip-prinsip dalam kode etik merupakan bagian penting dari profesionalisme dan menjadi pedoman dalam menjalankan tugas sebagai pengawas internal pemerintah daerah untuk menunjang kualitas pemeriksaan lebih baik. 4) Untuk meminimalkan bias akibat sedikitnya responden, maka penelitian sebaiknya dilakukan dalam cakupan yang lebih luas dengan menambah dan memperluas wilayah sampel dengan melibatkan Inspektorat kabupaten/kota. 5) Penelitian selanjutnya akan lebih baik jika menambahkan teknik pengumpulan data seperti wawancara langsung kepada responden, sehingga akan diperoleh data yang lengkap.

Pada penelitian ini, variabel independen yang diteliti berpengaruh terhadap variabel kualitas audit sebesar $78,8 \%$, berarti bahwa ada pengaruh sebesar $21,2 \%$ dari variabel-variabel lain di luar model. Penelitian selanjutnya disarankan untuk meneliti pengaruh variabel-variabel lain yang belum termasuk dalam model regresi pada penelitian ini.

\section{DAFTAR PUSTAKA}

Badan Pemeriksan Keuangan Republik Indonesia. 2016. Ikhtisar Pemeriksaa Hasil Pemeriksaan Semester 1 Tahun 2016.

Batubara, Rizal Iskandar, 2008. “Analisis Pengaruh Latar Belakang Pendidikan, Kecakapan Profesional, Pendidikan Berkelanjutan, dan Independensi Pemeriksa Terhadap Kualitas Hasil Pemeriksaan (Studi Empiris Pada Bawasko Medan)". Tesis. Universitas Sumatera Utara.

Batubara, 2009. Analisis Pengaruh Latar Belakang Pendidikan, Kecakapan Profesional, Pendidikan Berkelanjutan, dan Independensi Pememriksa Terhadap Kualitas Hasil Pemeriksaan (Study Empiris pada Bawasko Medan). (Tesis)

Effendy, Onong Uchyana. 2011. Ilmu Komunikasi: Teori dan Prakteknya, Bandung: Remaja Rosdakarya.

Ghozali, I. 2006. Aplikasi Analisis Multivariat dengan Program SPSS. Edisi $3 . \quad$ BP Undip. Semarang

Mulyadi, 2002. Auditing,Buku Dua, Edisi Ke Enam, Salemba Empat, Jakarta.

Oktarini, Ramantha, 2016. Pengaruh Pengalaman kerja dan Kepatuhan terhadap Kode Etik pada Kualitas Audit melalui Skeptisisme Profesional Auditor. E-jurnal Universitas Udayana Vol.15 April $2016: 475-783$.

Samsi, N. Akhmad Riduwan dan Bambang Suryono. 2013. Pengaruh Pengalaman Kerja, Independensi, dan Kompetensi Terhadap Kualitas Audit: Etika Auditor Sebagai Variabel Pemoderasi . Volume 1 Nomor 2 
Syamsidah, 2016 Pengaruh Latar Belakang Pendidikan, Pengalaman, Pendidikan Berkelnjutan, Ukuran Organisasi Dan Kompleksitas Pemerintahan Terhadap Kualitas Audit BPK RI (Studi Kasus pada Kementerian lembaga tahun 2014)

\section{Peraturan-peraturan:}

Undang-Undang Nomor 23 Tahun 2014 tentang Pemerintahan Daerah.

Undang - Undang Nomor 9 Tahun 2015 tentang perubahan kedua atas undang-undang nomor 23 tahun 2014 tentang pemerintahan daerah

Peraturan Pemerintah Nomor 4 Tahun 2008 Tentang Pedoman Pelaksanaan Reviu atas laporan Keuangan Pemerintah Daerah

Peraturan Menteri Dalam Negeri Nomor 28 tahun 2007 tentang Norma pengawasan dank ode etik pejabat pengawaas pemerintah

Peraturan Menteri Dalam Negeri Nomor 5 tahun 2005 tentang Standar Audit Internal Pemerintah

Peraturan Pemerintah Nomor 60 Tahun 2008 Tentang System Pengendalian Internal Pemerintah

Peraturan Menteri Negara Pendayagunaan Aparatur Negara Nomor PER/05/M.PAN/03/2008 Tentang Standar Audit APIP

Peraturan Menteri Negara Pendayagunaan Aparatur Negara Nomor PER/04/M.PAN/03/2008 Tentang Kode Etik Audit APIP

Peraturan Menteri Dalam Negeri Nomor 64 Tahun 2007 tentang pedoman Teknis organisasi dan Tata Kerja Inspektorat Provinsi dan Kabupaten/Kota

Peraturan Pemerintah Republik Indonesia Nomor 71 Tahun 2010 tentang Standar Akuntansi Pemerintah

Peraturan Badan Pemeriksa Keuangan Republik Indonesia No 01 Tahun 2007 tentang Standar Pemeriksaan Keuangan

Peraturan Daerah Kabupaten Kepulauan Talaud Nomor 31 Tahun 2008 badan pengawas daerah Kabupaten Kepulauan Talaud berubah menjadi Inspektorat Kabupaten Kepulauan Talaud

Standar audit intern Pemerintah Indonesia (Asosiasi Auditor Intern Pemerintah Indonesia) 